\title{
Britain finds way round impact of falling pound
}

London. Fears that Britain might have to reduce significantly its participation in international scientific projects as a result of last autumn's collapse of the pound have lifted, at least for now, after negotiations to reduce the impact of currency fluctuations.

Shortly before Christmas, Sir Mark Richmond, the chairman of the Science and Engineering Research Council (SERC), was warning that catastrophe could follow if Britain was required to meet the full increased costs of its membership in organizations such as the European Space Agency (ESA) and the European Laboratory for Particle Physics (CERN). At one point, Richmond even cast doubt on continued membership in these organizations, paid for in European Currency Units (ECUs) and Swiss francs respectively.

However, negotiations have reduced the impact of recent changes in the exchange rate. Space officials, facing an extra charge of $£ 20$ million, have negotiated the increase down to $£ 7$ million, and Britain's annual subscription to CERN actually has been reduced by $£ 3$ million from the $£ 57$ million previously anticipated.

The ESA negotiations centred on the procedure under which countries either top up their membership subscriptions or become eligible for refunds if exchange rates for converting national currencies into ECUs fluctuate widely after having been set at the beginning of the financial year. British ministers warned last November that, if this procedure were strictly applied, Britain would no longer be able to help finance the laboratory module being developed by ESA for the US space station.

With both Spain and Italy suffering from similar currency devaluations and Germany pushing hard for a reduction in the agency's overall budget to help pay for the country's reunification, ESA's governing board agreed on a new adjustment formula. Under this, member states that have suffered a devaluation in their currency relative to the ECU will pay only 35 per cent of the resulting extra costs. And those whose currencies have increased in value (primarily Germany and France) have agreed to accept only 50 per cent of the refunds to which they would otherwise have been entitled.

ESA must provide whatever additional money is needed, increasing the pressure to trim some activities. But British officials are relieved at the outcome. "Finding the extra $£ 7$ million out of an annual ESA subscription of about $£ 110$ million will still be difficult. But it will certainly be much easier than finding $£ 20$ million", said one.
A lower subscription price to CERN is the result of three factors. One was Britain's agreement last summer to make an advance payment on its 1993 subscription to help the organization with a temporary financial problem. The second was the financial implications of devaluation itself, which will reduce Britain's subscription to CERN based on an assessment of "net national income" - from 15.2 per cent of the laboratory's total budget in 1992 to 13.5 per cent in 1993.

The third factor was the decision last December by the CERN council, again primarily under pressure from Germany, to reduce the laboratory's 1993 budget by 3 per cent (or $\$ 10$ million). No decisions have been made on how these cuts will be achieved, although the installation of new equipment and perhaps certain experiments are expected to be delayed.

Half of Britain's savings from its reduced subscription will be returned to the SERC's central fund and redistributed according to the council's scientific priorities. The other half will be returned to the nuclear physics board and reallocated to domestic research projects.

Nuclear physics, however, is not yet out of the woods. The SERC has offered up three programmes in response to a request from the Advisory Board for the Research Councils (ABRC) for suggested ways to absorb hypothetical cuts of 2,4 or 6 per cent in next year's budget.

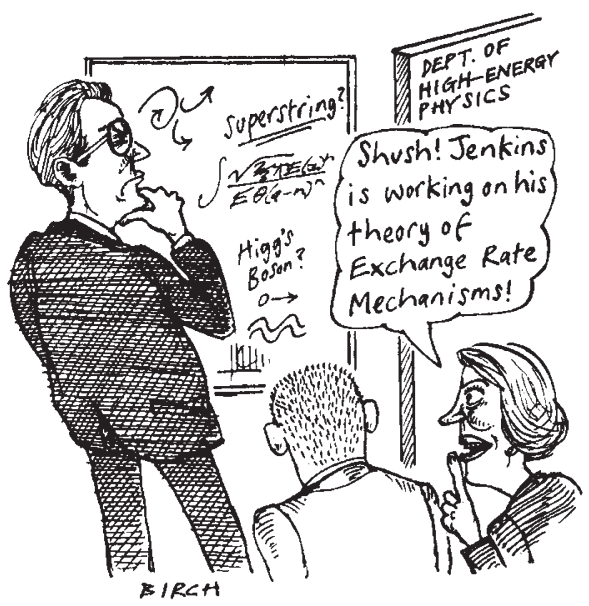

One would be to abandon all domestic research into nuclear structure, a move that the council prefers to opting out of CERN's plans for a new particle accelerator, the Large Hadron Collider. The other two programmes are British participation in ESA's $\mathrm{X}$-ray Multi-Mirror space mission and the Vulcan high-energy laser facility at the Rutherford Appleton Laboratory.

Physicists feel that they have been unfairly singled out by the SERC as potential victims of the ABRC budget knife. The Institute of Physics has written to Richmond in protest, pointing out that a special review carried out for the SERC two years ago concluded that nuclear structure research in Britain "is of high quality and enjoys an international reputation". It has asked for an assurance that programmes in other disciplines be subject to the same degree of scrutiny before decisions are made about what programmes might be cut.

David Dickson

\section{Russia sets up system for individual grants}

Moscow. The Russian Foundation for Fundamental Research has begun accepting proposals for the first round of peerreviewed research grants to individuals. But a deadline of 15 March for the distribution of the first quarter of its annual budget of 7.7 billion rubles (US\$15 million) has forced the foundation to move more quickly than it would like, jeopardizing its promise to rely on experts in the various fields and to bypass the bureaucrats who controlled funding in the former Soviet Union.

The foundation, using government funds, hopes to give grants of up to 5 million rubles to individuals or small research teams. About 60 per cent will be spent directly on research, with 7.5 per cent for international travel and collaboration and 7.5 per cent to publish results. The remaining 25 per cent would go to the institution for overhead costs. The foundation is expected to make 200-300 grants initially from a pool of several thousand applicants.

Meeting recently for the first time, the foundation's board of directors, composed primarily of the heads of several well-respected institutes, defined six broad areas of support. Each area will have a council of experts of a dozen or so members reviewing proposals, although there is no guarantee that every proposal will be judged by an expert in that field.

The foundation is headed by Andrei Gonchar, vice president of the Russian Academy of Sciences. Gonchar is heartened by the existence of the International Science Foundation, created last autumn by US businessman George Soros to distribute US $\$ 100$ million in grants to individual researchers throughout the former Soviet Union. Gonchar hopes that the Soros foundation will be a model for the Russian foundation to follow and perhaps even a healthy competitor in seeking out the best applicants.

Vladimir Pokrovsky 